\title{
Standart Yağış Indeksi(SPI) Metodu Kullanılarak Kuraklık Analizi ve Bursa Doğancı Barajı ile Ilişkilendirilmesi
}

\author{
${ }^{1 *}$ Gülnaziye Özgün, ${ }^{2}$ Babak Vaheddoost, and ${ }^{3}$ Egemen Aras \\ Department of Civil Engineering, Bursa Technical University, Bursa-Turkey \\ ${ }^{1}$ MSc Student, e-mail: gul95ozgun@gmail.com \\ ${ }^{2}$ Dr., e-mail: babak.vaheddoost@btu.edu.tr \\ ${ }^{3}$ Prof. Dr., e-mail: egemen.aras@ btu.edu.tr
}

\section{Özet}

İklim değişikliği, tüm dünyayı tehdit etmeye başlayan çok ciddi bir sorundur. İklim değişikliğini belirlemek için kullanılan en önemli kavramlardan birisi kuraklıktır. Kuraklığın temelinde yağışlardaki geçici düşüşler vardır. Küresel iklim değişikliğinin sonucu dünyanın birçok bölgesinde artan sıcaklıklar ve azalan yağışlar, kuraklık olaylarının sıklığını ve ciddiyetini artırır. Kuraklığın belirlenmesi ve gerekli tedbirlerin alınabilmesi için bölgenin ayrıntılı analizi gerekmektedir. Araştırmacılar, kuraklığı saptamak için farklı kuraklık indekslerini kullanmışlardır. Standart Yağış İndeksi (SPI), farklı zaman ölçeklerinde hesapların yapılabildiği ve literatürde en çok kullanılan kuraklık indekslerinden biridir. Bu çalışmada, Bursa ilinde Doğancı Barajı'nın 1982-2013 dönemi için yağış ve debi verisi incelenmiştir. Standart Yağış İndeksi (SPI) yöntemi ile 1, 6, 12, 24 ve 48 aylık zaman periyotları için kuraklık analizi yapılmıştır. Standart Yağış İndeksi (SPI) analizi sonuçlarında, 12 aylık zaman periyodu için yapılan analiz dikkate alınmıştır. 12 aylık analize göre Doğancı Barajı'nın olduğu bölgede kuraklık indekslerine göre bölgenin kuraklık/nemlilik durumu gözlenmiştir. SPI değerleri ile baraja gelen debi ilişkilendirilmişstir. Değerlendirmede kuraklığın etkisiyle baraja gelen debi arasındaki etkileşime bakılmıştır. Kuraklık önlenmesi, iklim değişikliği ve barajlar açısından öneriler sunulmuştur.

Key Words: SPI, Kuraklık, Doğancı Barajı

\section{Drought Analysis Using Standard Precipitation Index(SPI) Method and Associating with Bursa Doganci Dam}

\begin{abstract}
Climate change is a serious problem that is threatening the whole world. Drought is one of the most important concepts used to determine climate change. The drought is based on temporary decreases in precipitation. Increasing temperatures and decreasing precipitation in many parts of the world as a result of global climate change increase the frequency and severity of drought events. A detailed analysis of the region is required to determine the drought and take the necessary precautions. Researchers used different drought indices to detect drought. Standard Precipitation Index (SPI) is one of the most widely used drought indices in the literature. SPI calculations can be made at different time scales. In this study, precipitation and discharge data of Doganci Dam in Bursa for 1982-2013 period were investigated. Drought analysis was performed for the 1, 6, 12, 24 and 48-month time periods using Standard Precipitation Index (SPI) method. Results of the Standard Precipitation Index (SPI) analysis were taken into consideration for the 12-month period. According to the 12-month analysis, the drought / humidity level of the region was observed according to the drought indices in the region. SPI values and the flow to the dam are correlated. In the evaluation, the interaction between the drought and the flow to the dam was examined. Recommendations were made in terms of drought prevention, climate change and dam management.
\end{abstract}

Keywords: SPI, Drought, Doganci Dam

* Corresponding author: Gülnaziye ÖZGÜN. Address: Mühendislik ve Doğa Bilimleri Fakültesi, İnşaat Mühendisliği Bölümü, Bursa Teknik Üniversitesi, 16290, Bursa TÜRKİYE.

E-mail address: gul95ozgun@gmail.com 


\section{Giriş}

İklim değişikliği bugünlerde insanlığın karşılaştığı en büyük ve karmaşık problemlerden biridir. Ülkemiz Akdeniz Havzası içerisinde yer alır. Akdeniz Havzası, iklim değişikliğine karşı en hassas bölgelerden birisidir. Akdeniz Havzası'nda gerçekleşecek $2^{\circ} \mathrm{C}$ 'lik bir sıcaklık artışı, beklenmeyen hava olayları, sıcak hava dalgaları, orman yangınlarının sayısında ve etkisinde artış ve bunlar dolayısıyla biyolojik çeşitlilik kaybı, turizm gelirlerinde azalma, tarımsal verim kaybı ve en önemlisi kuraklık olarak etkilerini hissettirecektir.

İklim değişimi nedeniyle etkisi her geçen zaman daha fazla hissedilen kuraklık, yağışların, kaydedilen normal seviyelerinin önemli ölçüde altına düşmesi sonucu, arazi ve su kaynaklarının olumsuz etkilenmesine ve hidrolojik dengenin bozulmasına sebep olan doğal olay olarak tanımlanır[1]. Kuraklığın temelinde yağışlardaki geçici düşüşler vardır. Küresel iklim değişikliğinin sonucu dünyanın birçok bölgesinde artan sıcaklıklar ve azalan yağışlar, kuraklık olaylarının sıklığını ve ciddiyetini artırır. Yağışlardaki azalma nedeniyle kuraklığın etkisi su kaynaklarında daha fazla hissedilir. Meteorolojik kuraklığın su kaynakları üzerine etkisi hidrolojik kuraklıktır. Meteorolojik ve hidrolojik kuraklıklar tarımsal kuraklığa ve sosyoekonomik kuraklığa sebep olur. Bu yüzden kuraklık zamanında tespit edilmez ve gerekli önlemler alınamazsa ülkelerin ekonomisine büyük zararlar verir.

Kuraklık akarsular için düşük akım demektir. Düşük akım dönemlerinde akarsudaki debi, hız ve derinlik normalden çok daha küçük değerlerdedir. Bunun olumsuz ekolojik ve sosyoekonomik etkileri vardır. Örneğin, akarsudan su sağlama, akarsuda ulaşım, elektrik üretimi, akarsuda balıkların ve diğer canlıların yaşamı ile çevre estetiği olumsuz şekilde etkilenir; akarsudaki erimiş madde yoğunluğu artar. Bunun yanı sıra endüstri, şehir ve sulama suyu dönüşleri de akarsuyun kalitesini bozar. Akım hızının azalması akarsuyun havalandırma potansiyelini azaltır. Kirleticilerin geçiş hızı da azalacağından kirlenme tehlikesi artar [2].

Kuraklığın belirlenmesinde, meteorolojik istasyonlardan yersel olarak ölçülen veriler (yağış ve sıcaklık gibi) kullanılarak oluşturulan Standart Yağış İndisi (SPI), Normalin Yüzdesi İndeksi ve PALMER Kuraklık Şiddet İndeksi gibi meteorolojik kuraklık indislerinden yararlanılır. Standart Yağış İndisi (SPİ) ile farklı ülkelerde pek çok çalışma yapılmıştır. Bunlardan bazı çalışmalar şunlardır; Topçu ve Seçkin [3], 11 istasyonda SPİ yöntemiyle Seyhan Havzası'nın kuraklık durumu incelenmiştir. SPİ yöntemiyle belirlenen en kurak ayların yağış değerlerine Lmomentler yöntemiyle bölgesel frekans analizi uygulanmıştır. Gocic ve Trajkovic [4], Sırbistan'da 1948-2012 dönemleri için kuraklık analizi yapmışlardır. Zarch vd. [5], SPİ ve yağışın yanında Potansiyel Evapotranspirasyon (PET) verileri dikkate alınarak hesaplanan Keşif Kuraklık İndisi (RDI) kullanılarak kuraklık analizi yapmışlardır. Guhathakurta vd. [6], Hindistan'1 5 alt bölgeye ayırarak 1901-2015 yılları arasında kuraklık analizi yapmıştır. Labedzki [7], Polonya'da SPİ kullanarak yağış koşullarını değerlendirmiştir.

$\mathrm{Bu}$ çalışmada, yersel meteorolojik veriler ile akım gözlem istasyonlarından alınan debi verileri değerlendirilerek, yıllar boyunca kuraklık değiş̧imini ve baraja gelen debi değişimini inceleyerek kuraklık konusunda bir yorum yapmak hedeflenmektedir. Bu hedef doğrultusunda Bursa İl sınırları içerisinde bulunan Doğancı Barajı'nın yağışlı ve kurak dönemlerdeki debi değişimi ve bu değişim ile meteorolojik kuraklık arasındaki etkileşim incelenmiştir. Meteorolojik kuraklık; SPI indeksi kullanılarak belirlenmiştir. Yıllara göre baraj bölgesindeki kuraklık ve nemlilik durumları incelenmiş, düşen maksimum ve minimum yağışlar gözlemlenmiştir. Yağış ve debi arasındaki korelasyon katsayıları bulunup yorumlar yapılmıştır. 


\section{Materyal ve Metot}

Marmara Bölgesi ile Ege Bölgesi geçiş alanında yer alması nedeniyle Bursa iklimi değişik ve karmaşık bir yapıya sahiptir. Bursa genel olarak 1lıman bir iklim yapısına sahip olmakla birlikte kendi içerisindeki bölgelere göre de değişkenlik göstermektedir. Şehrin kuzey bölgelerinde Marmara Bölgesi'ne özgü olan 1lıman iklim tipi yoğunluklu olarak hissedilirken, şehrin güney ve iç bölgelerinde karasal iklim özellikleri hissedilir. Temmuz, ağustos ve eylül ayları Bursa'nın en sıcak ayları olarak kabul edilirken, şubat ve mart ise; şehrin en soğuk ayları olarak kabul edilmektedirler[8].

Doğancı Barajı, Bursa ilinin Osmangazi ilçesinde, Nilüfer Çayı üzerinde, şehre içme suyu temin etmek amacıyla 1975-1982 yılları arasında inşa edilmiş bir barajdır. Baraj gölünü besleyen iki kolu vardır. Toprak ve kaya gövde dolgu tipi olan barajın gövde hacmi, 2.520.000 metreküp, akarsu yatağından yüksekliği 65 metre, maksimum su kotunda göl hacmi 37.80 hektometreküp, normal su kotunda göl alanı 1.55 kilometrekaredir[9]. Yılda 125 hektometreküp içme suyu sağlamaktadır. Baraj gölü alanı Şekil 1'de gösterilmiştir.

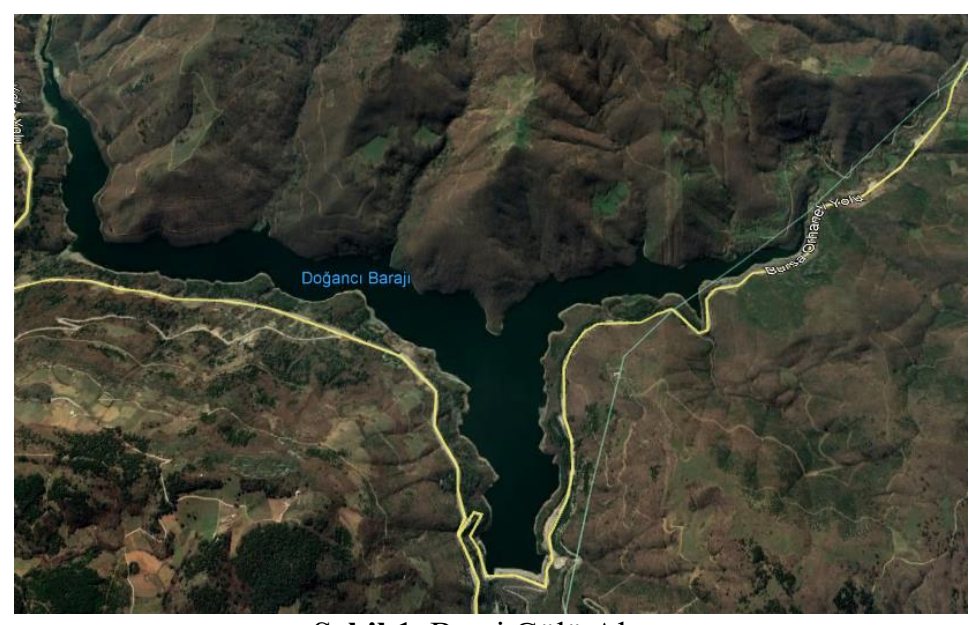

Şekil 1. Baraj Gölü Alanı

Bu çalışmada kullanılan Bursa ilinde DSİ (Devlet Su İşleri)'ye ait akım gözlem istasyonları, baraj gölüne gelen iki kola aittir. Birinci kola ait istasyon, Susurluk Havzası içerisinde, D03A044 kodlu Nilüfer Çayı Selahattin Saygı Baraj Giriş isimli, Eski Orhaneli-Keles Yolunun yol ayrımındaki köprünün $150 \mathrm{~m}$. mansabında sağ sahilde, $29^{\circ} 0^{\prime} 5^{\prime \prime}$ Doğu enlemi - 40 ${ }^{\circ} 5^{\prime} 7^{\prime \prime}$ Kuzey boylamındadır. İkinci kola ait istasyon ise, Susurluk Havzası içerisinde, D03A056 kodlu Sultaniye Deresi isimli, Bursa Orhaneli yolunun $20 \mathrm{~km}$ 'sindeki eski kemer köprünün $50 \mathrm{~m}$ mansabında, 2856'28" Doğu enlemi- 405'57" Kuzey boylamındadır. Yağıș verileri DSİ'den alınan, Doğancı Barajı'nda ölçülen verilerdir.

\subsection{Standart Yağış İndeksi (Standardized Precipitation İndex-SPI)}

McKee vd. [10] tarafından geliştirilen Standart Yağış İndisi (SPI) yöntemi, kuraklığı izlemek için yaygın olarak kullanılan yöntemlerden biridir. Farklı süreli periyotlar için analiz yapılabilir. Boyutsuz bir kuraklık indisidir. Yağış veri serisi öncelikle uygun bir olasılık dağılımı içine uygulanır. Olasılık yoğunluk fonksiyonu belirlendikten sonra, gözlenen bir yağış miktarının kümülatif olasılığı hesaplanır. Daha sonra, Gauss fonksiyonu, kümülatif olasılığa uygulanır. Buradan SPI hesaplanır [11,12]. 
SPI normalleştirilmiş olasılık dağılımı yardımıyla hem kuru hem de nemli bölgelerde uygulanabilir. SPI'nin değeri, belirli bir olasılık dağılım fonksiyonunun ölçülen yağışın standart sapmasını ifade eder. Varsayılan x araştırma zaman ölçeği (1 ay, 6 ay, 12 ay, 24 ay, 48 ay) kümülatif aylık yağıştır. Thom [13], Gama olasılık dağılımının klimatolojik zaman serilerine en uygun dağılım olduğunu ortaya koymuştur.

Bu yöntem, yağıştaki meydana gelen azalmanın yeraltı suyu, su biriktirme haznesi depolaması, zemin nemi, kar yığını ve akarsu gibi hidrolojik sistemler üzerindeki etkilerini belirlemek amacıyla geliştirilmiştir. Zaman dilimleri, çeşitli su kaynaklarının uygunluğunda kuraklık etkilerini yansıtmaktadır. Bu yöntemde ihtiyaç duyulan tek meteorolojik değişken yağgş olduğu için uygulaması kolaydır. Diğer bir önemli avantajı ise farklı zaman ölçekleri için kuraklığı ölçmede gösterdiği esnekliktir. Standart yağış serisini hesaplamada sadece yağış serisinin aritmetik ortalaması ve standart sapması gereklidir. Herhangi bir $X_{1}, X_{2}, \ldots ., X_{n}$ yağış zaman serisi için standart yağış serisi, $x_{i}$, aşağıdaki eşitlik kullanılarak hesaplanır. Burada $\bar{X}$ serinin ortalamasını ve $S x$ ise serinin standart sapmasını gösterir.

$$
x i=\frac{x i-\bar{x}}{S x}
$$

Yağış eksikliğinin farklı su kaynaklarına etkisi dikkate alınarak genel olarak indekslerdeki değişimlerin gözleneceği 1, 6, 12, 24 ve 48 aylık gibi farklı zaman dilimleri belirlenir. Bu zaman dilimleri yağıştaki eksikliğin su kaynaklarına olan etkisinin ne kadar sürede hissedilebileceğine göre seçilmiştir. Genellikle, yağış serileri normal olmayan bir dağılıma sahiptir. Yağış, 12 ay ve daha az periyotlarda normal dağılıma uymadığ için, yağış serileri öncelikle normal dağılıma uydurulur. SPI değerleri, yağış ile lineer olarak artan veya azalan bir eğilim gösterir. SPI değerlerinin normalize edilmesi sonucunda seçilen zaman dilimi içerisinde, hem kurak ve hem de nemli dönemler aynı şekilde temsil edilir. SPI değerleri dikkate alınarak yapılan bir kuraklık değerlendirmesinde indeksin sürekli olarak negatif olduğu zaman periyodu kurak dönem olarak tanımlanır. İndeksin sıfırın altına ilk düştüğü dönem kuraklığın başlangıcı olarak kabul edilirken, indeksin pozitif değere yükseldiği ay kuraklığın bitimi olarak değerlendirilir [14].

Meteoroloji Genel Müdürlüğü'ne ait, SPI metoduna göre indeks değerleri ve onlara karşılık gelen sınıflandırmalar tablosu Tablo 1'de verilmiştir.

Tablo 1. SPI Metoduna Göre İndeks Değerleri Ve Sınıflandırma [1]

\begin{tabular}{ll}
\hline SPI indis değerleri & Sınıflandırma \\
\hline 2.0 ve fazla & Olağanüstü Nemli \\
1.60 ile 1.99 & Aşırı Nemli \\
1.30 ile 1.59 & Çok Nemli \\
0.80 ile 1.29 & Orta Nemli \\
0.51 ile 0.79 & Hafif Nemli \\
0.50 ile -0.50 & Normal Civarı \\
-0.51 ile -0.79 & Hafif Kurak \\
-0.80 ile -1.29 & Orta Kurak \\
-1.30 ile -1.59 & Şiddetli Kurak \\
-1.60 ile -1.99 & Çok Şiddetli Kurak \\
-2 ve düşük & Olağanüstü Kurak \\
\hline
\end{tabular}




\subsection{Korelasyon Analizi}

İki sayısal ölçüm arasında doğrusal bir ilişki olup olmadığını, varsa bu ilişkinin yönünü ve şiddetininin ne olduğunu belirlemek için kullanılan istatistiksel yöntemdir. Korelasyon katsayısı(r) negatif ise iki değişken arasında ters ilişki vardır, yani "değişkenlerden biri artarken diğeri azalmaktadır" denir. Korelasyon katsayısı (r) pozitif ise "değişkenlerden biri artarken diğeri de artmaktadır" yorumu yapılır. Korelasyon katsayısı(r), 0.2 den küçükse veriler arasında zayıf ilişki vardır ya da ilişki yoktur denir. Değişkenler arasında korelasyon katsayısı 0.2 ve 0.4 arasındaysa zayıf korelasyon, 0.4 ve 0.6 arasındaysa orta şiddette korelasyon, 0.6 ve 0.8 arasındaysa yüksek korelasyon ve 0.8 den büyükse çok yüksek korelasyon olduğu anlaş1lır[15].

\section{Bulgular}

\subsection{Doğancı Barajı Kuraklık Analizi}

SPI Kuraklık Analizi için öncelikle aylık ortalama yağış verileri MS Excel programında yıllar ve aylara göre düzenlenmiştir. Düzenlenen veriler MATLAB programına ZimaSPI uzantısı aracılığıyla yüklenmiştir. Yüklenen aylık ortalama yağış verileri kullanılarak 1, 6, 12, 24 ve 48 aylık zaman ölçekleri için SPI zaman serileri elde edilmiş ve Şekil 2, Şekil 3, Şekil 4, Şekil 5 ve Şekil 6'da gösterilmiştir. Bu şekilde, farklı periyotlardaki kurak ve sulak dönemler, bu dönemlerin sıklığı ve kuraklık özellikleri hakkında gözlemler yapılmıştır. Farklı periyotlardaki maksimum ve minimum SPI indeks değerleri gözlemlenmiştir.
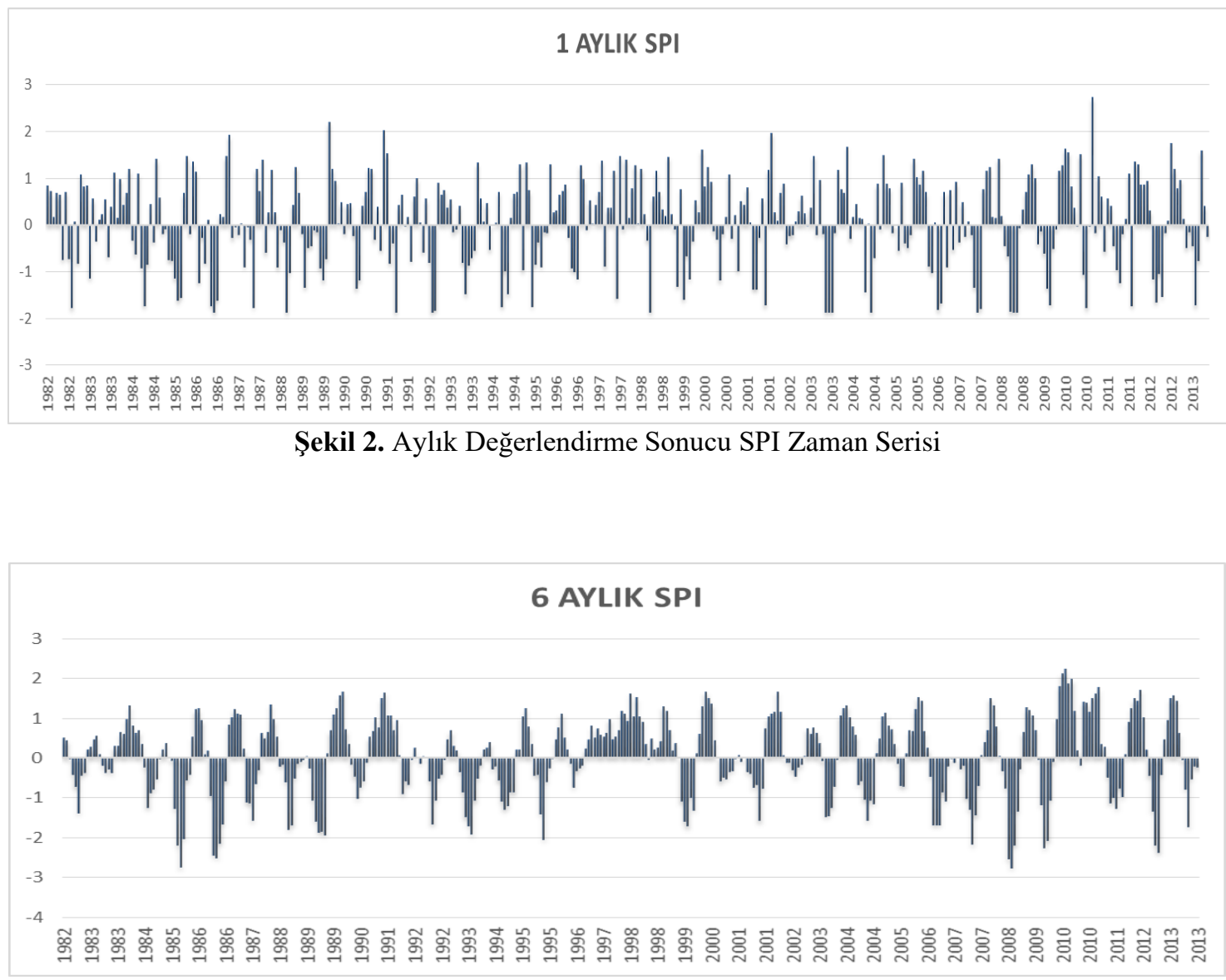

Şekil 3.6 Aylık Değerlendirme Sonucu SPI Zaman Serisi 


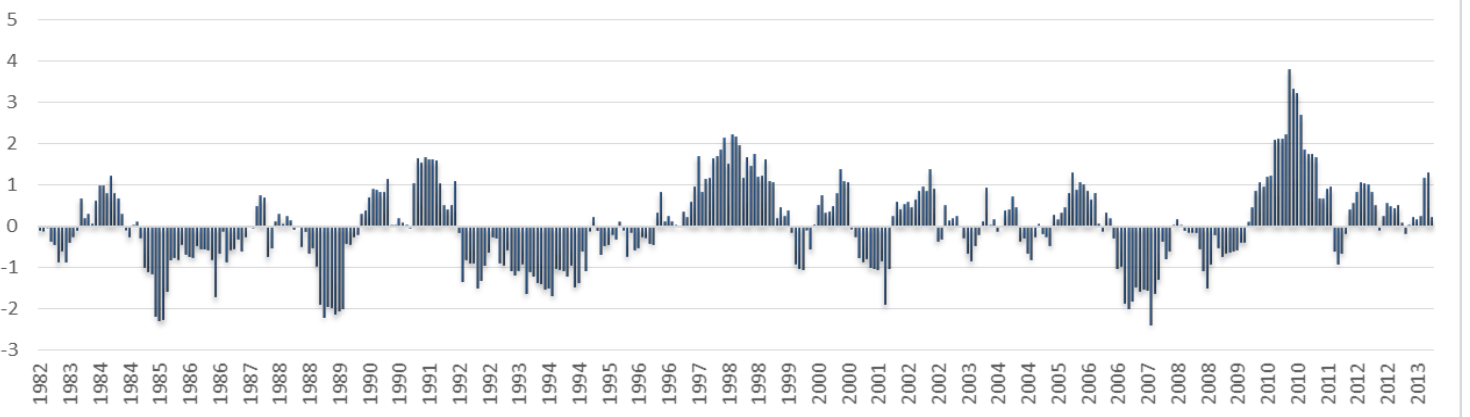

Şekil 4. 12 Aylık Değerlendirme Sonucu SPI Zaman Serisi

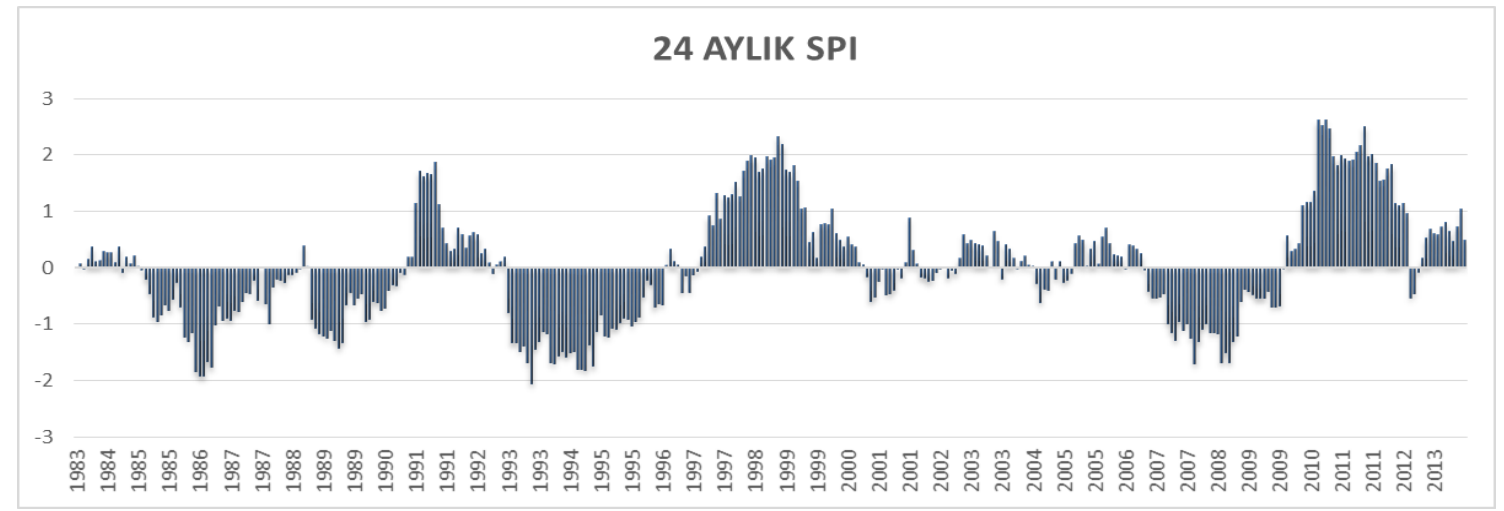

Şekil 5. 24 Aylık Değerlendirme Sonucu SPI Zaman Serisi

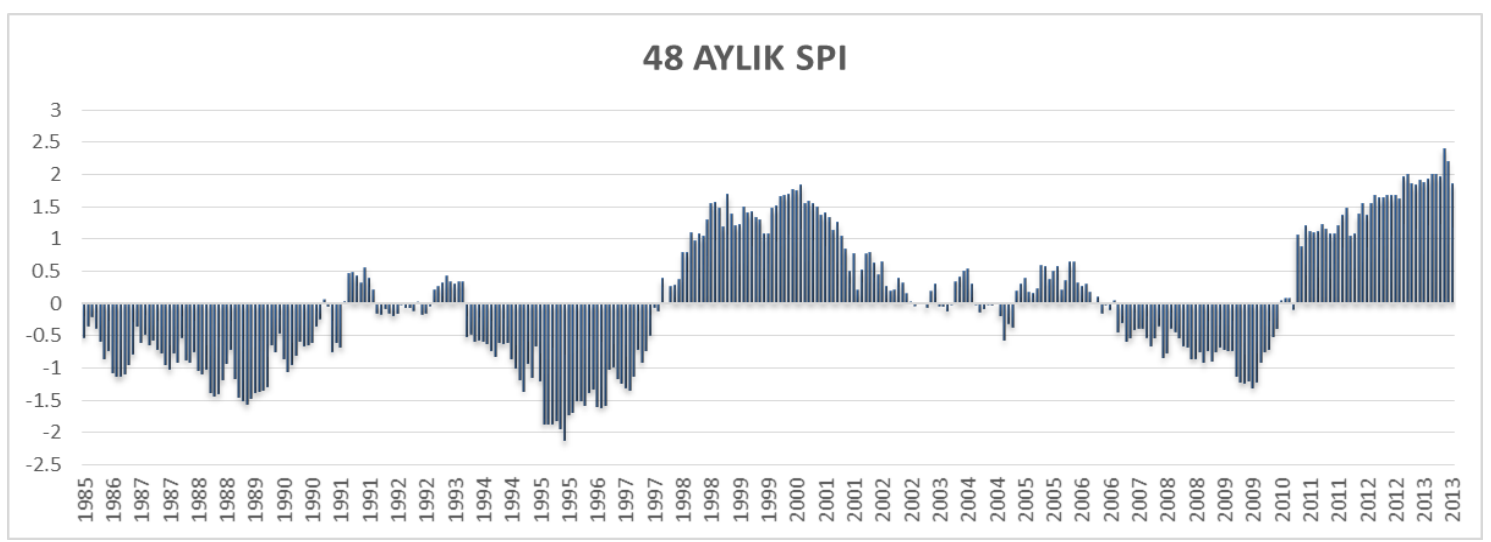

Şekil 6.48 Aylık Değerlendirme Sonucu SPI Zaman Serisi

SPI analizinin 1 aylık, 6 aylık, 12 aylık, 24 aylık ve 48 aylık analiz edilmesi sonucunda elde edilen maksimum ve minimum SPI değerleri incelenmiștir. Maksimum ve minimum SPI değerleri Tablo 2'de verilmiştir. Verilen maksimum ve minimum SPI değerlerine göre 12 aylık analizin maksimum değeri en büyük ve minimum değeri de en düşük değere yakın olduğu için, 12 aylık analiz sonuçları değerlendirilicektir. 
Tablo 2. Farklı Zaman Ölçekleri İçin Maksimum Ve Minimum SPI Değerleri

\begin{tabular}{lll}
\hline & Maksimum SPI & Minimum SPI \\
1 Aylık & 2.726 & -1.863 \\
6 Aylık & 2.221 & -2.761 \\
12 Aylık & 3.782 & -2.384 \\
24 Aylık & 2.623 & -2.052 \\
48 Aylık & 2.400 & -2.128 \\
\hline
\end{tabular}

Bölgesel ortalama 12 aylık SPI serisine bakıldığında, 1982-2013 y1lları arasındaki değerlendirme sonucunda, toplam 31 yılda toplam 9 kez 6 ay ve üzeri süren bir kuraklık, toplam 12 kez 6 ay ve üzeri süren bir nemlilik gözlenmiştir. Bunlardan en uzun süren kuraklık süreci 1992 yılı nisan ayından başlayıp, 1995 yılının mart ayı sonunda sona ermiştir. Bu süreç içerisinde en yüksek dereceli kuraklık değeri -1.67 ile 1994 yılının mayıs ayında görülmüştür. $\mathrm{Bu}$ değer SPI indis değerlerine göre "çok şiddetli kurak" olarak nitelendirilmiştir. Yıllar boyunca görülen en düşük SPI değeri ise 2007 yılının eylül ayına aittir. Belirtilen ayda SPI indis değeri -2.38 ile “olağanüstü kurak” sınıfındadır. IPM Kuraklık Raporu(24.10.2014)'na göre bu kuraklık olaylarının uzun süreli olanları meteorolojik kuraklık olarak başlayıp daha sonra tarımsal ve hidrolojik kuraklık halini de almıştır. Son olarak Kasım-Aralık 2006' dan başlayarak Aralık 2008'e kadar süren 2007-2008 kuraklık döneminde, özellikle sonbahar ve kış aylarında yağışlar Türkiye'nin birçok yöresinde uzun süreli ortalamaların altında kalmıştır. Bu durum ise, o dönemde yeni bir meteorolojik kuraklık olayları dizisinin yaşanmasına ve bunlara bağlı olarak da tarımsal, hidrolojik ve sosyoekonomik kuraklıkların oluşmasına neden olmuştur.

Yıllar boyunca en çok yağış alan aylardaki SPI değişimi Şekil 7'de gösterilmektedir. Grafiğe bakılarak, indekslerin genel olarak normal civarında seyrettiği görülmektedir. Fakat yıllar geçtikçe kuraklık görülen yılların ardarda gelmesi artmıştır. Görülen kuraklıklarda SPI maksimum değerlerinin de gitgide arttığı görülmektedir. Yani oluşan her kuraklıkta, bir önceki ciddi kuraklığa göre daha da yüksek dereceli bir kuraklık yaşanıyor denilebilir. Görülen bu kuraklık değişimlerinin yanısıra, 1998 itibariyle bölgeye belirli aralıklarla normalde görülen yağıştan fazlası düşmeye başlamıştır. Bu yüksek miktarda görülen yağışların 10 yıl gibi bir sürede tekrar ettiği ve bu periyotlarda görülen maksimum yağışın da bir önceki nemli döneme göre arttı̆̆ gözlemlenmiştir.

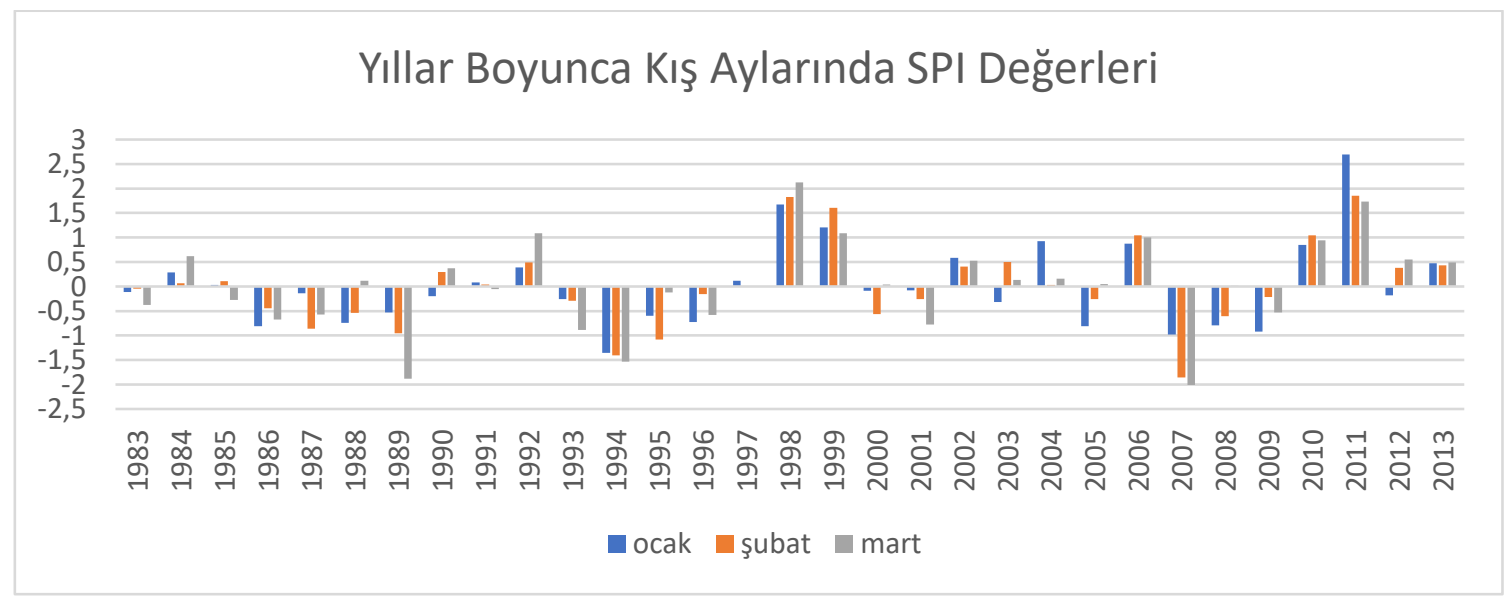

Şekil 7. Yıllar Boyunca Kış Aylarında SPI Değişimi 
En uzun süren nemlilik ise 1997 yılının nisan ayında başlayıp, 1999 yılının ağustos ayı sonunda bitmiştir. $\mathrm{Bu}$ süreçte en yüksek SPI değeri 2.2 ile 1998 yılının mayıs ayına aittir. Sınıflandırmaya göre bu değer, "olağanüstü nemli" olarak nitelendirilmiştir. Tüm yıllara bakıldığında görülen en yüksek SPI değeri 2010 yılı ekim ayında 3.78 ile dikkat çekmektedir. Ayrıca, yazın gerçekleşen yağışlar ile ilgili, yıllar geçtikçe SPI değerlerinin -2 değerlerinden sıfıra yaklaşmaya başladığı, yani yazın aşırı yağışların arttığı görülür. Fakat bu aşırı yağışların arasındaki süre de artmıştır. $\mathrm{Bu}$ da artan kuraklığın önemli göstergelerinden biridir. Yıllar boyunca yaz aylarında görülen SPI değerleri Şekil 8'de gösterilmektedir.

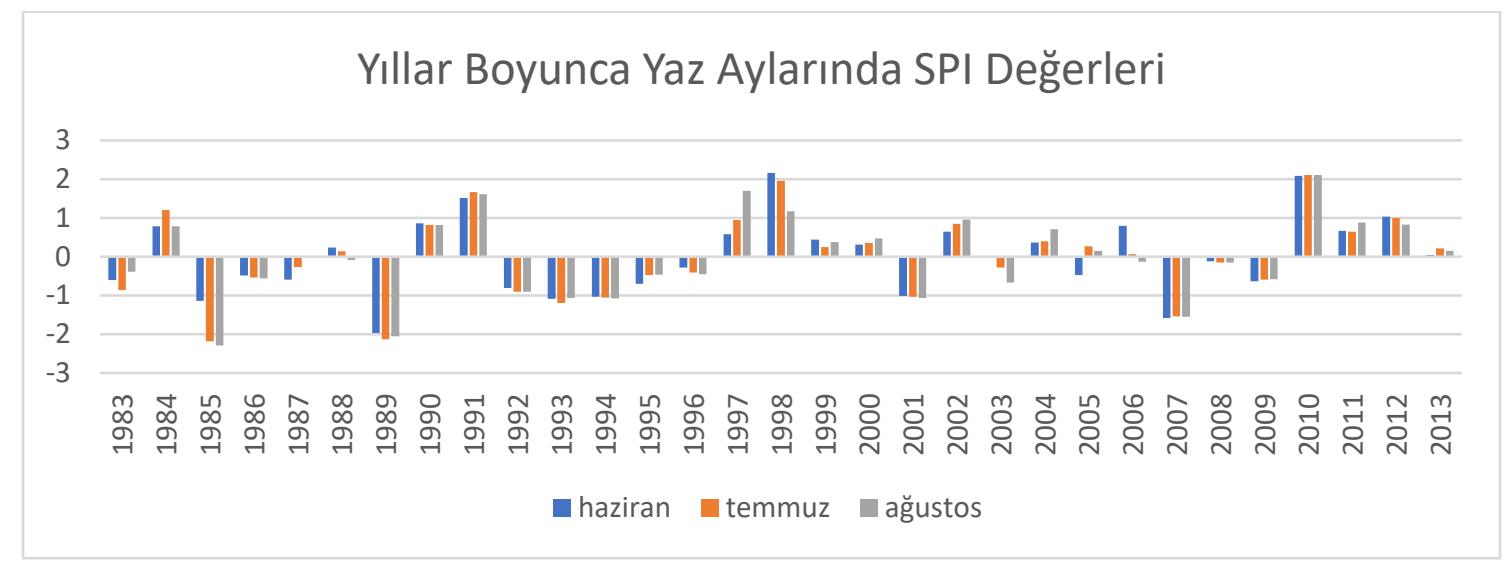

Şekil 8. Yıllar Boyunca Yaz Aylarında SPI Değerleri

\subsection{Korelasyon Analizi}

Bulunan SPI değerleri ile baraja gelen toplam debinin değişimi grafiği Şekil 9'da verilmiştir. Grafiğe bakıldığında, SPI değişimine bağlı olarak, debinin de aynı yönde değiştiği, aralarında pozitif bir ilişki olduğu görülmektedir. MS Excel programında yapılan korelasyon analizi çalışmasında ise, yağışın akış üzerinde hemen etkili olmadığı, aynı aylar için korelasyon analizi yapıldığında korelasyon katsayısı r=0.344, bir sonraki aylar için korelasyon analizi yapıldığında korelasyon katsayısı $\mathrm{r}=0.435,2$. ay için korelasyon yapıldığında $\mathrm{r}=0.427,3$. ay için korelasyon analizi yapıldığında $\mathrm{r}=0.368$ değerleri görülmüştür. Bu şekilde devam edilerek korelasyon katsayılarına bakıldığında ilişkilerin düştüğü görülmüştür. Bu da demektir ki, bir ayda yağan yağış toplamının etkisini sonraki iki ay içerisinde daha iyi görülmektedir. Yağan yağışın etkisi aylar geçtikçe azalmaktadır. Katsayıların düşük olması ise, yağış ve akış arasında \%100 bir ilişki olmamasından kaynaklıdır. Akarsuya gelen debiyi yağışla beraber, yeraltı suyunun durumu,zemin özellikleri, zeminin geçirimliliği, akarsu yatağının dar veya geniş olması, sıcaklık,buharlaşma miktarı, akarsu çevresindeki bitki örtüsü durumu, havzaya yakın olan dağlardaki kar durumu gibi faktörler de etkilemektedir. Bu yüzden sadece yağışa bakılarak baraja gelen debinin tahmin edilmesi zordur. 


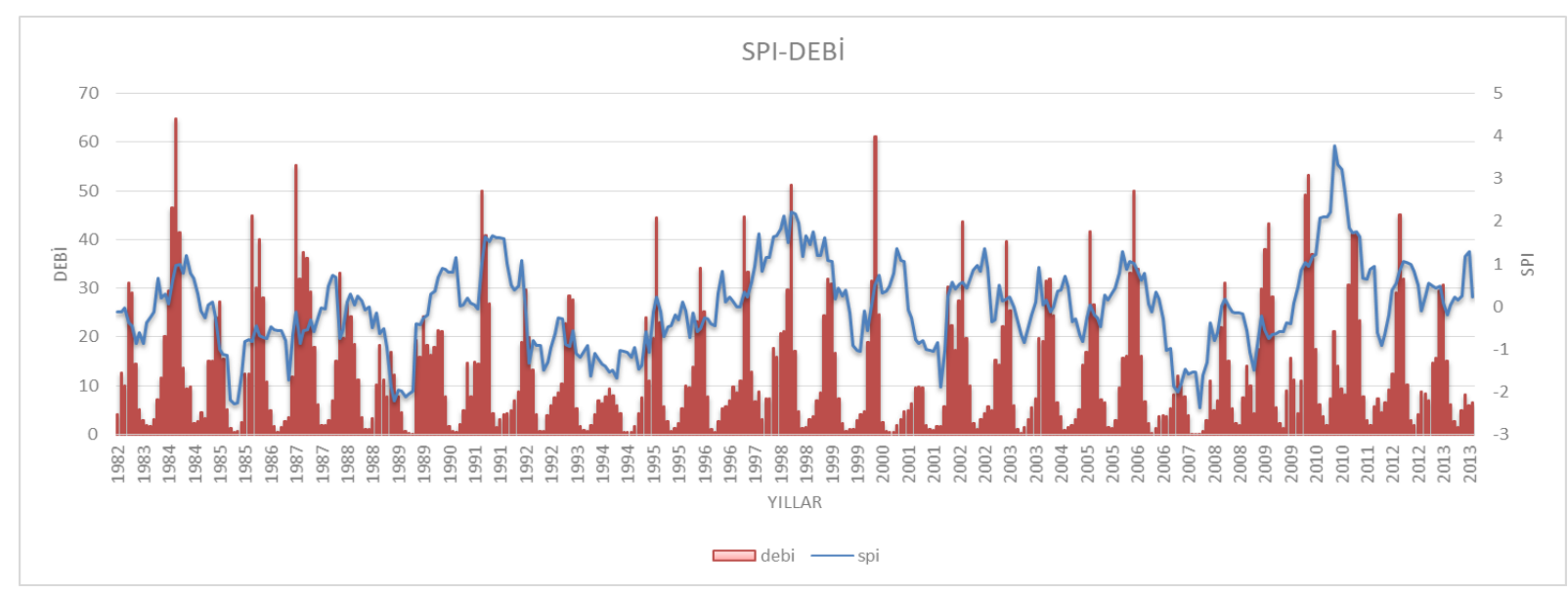

Şekil 9. SPI ve Debi İlişkisi

\section{Sonuçlar}

İklim değişikliğine bağlı olarak kuraklık, ülkemizi ve tüm dünyayı etkileyen ve ileride daha da etkileyeceği öngörülen bir afettir. Kuraklığın ülkeler üzerindeki etkisi zamanında ve doğru olarak belirlenmelidir. Kuraklığın neyi, ne boyutta etkileyeceği belirlenmelidir. Çalışma sonucunda elde edilen bazı sonuçlar aşağıda verilmiştir:

·Çalışma alanında en çok yağış kış mevsiminde düşmektedir. Kışın düşen yağış miktarı genel olarak normal civardadır. Fakat SPI değerleri sıfırdan düşük olan yıl miktarı sıfırdan fazla olan yıl miktarına göre artmaya başlamıştır. SPI değerlerinin ekside kaldığı yılların ardarda daha çok gelmeye başladığı görülmüştür.. Bu da yıllar geçtikçe bu bölgede kış aylarında beklenen yağışların az miktarda düşeceği, kuraklığın yavaş yavaş görülmeye başlandığı anlamına gelebilir.

- Bunun yanında kış aylarında ortalama 10 yılda bir olarak görülen bir fazla yağış durumu mevcuttur. Barajın yapıldığı 1982 döneminde kış ayında SPI değerlerinde herhangi bir anormallik görülmemektedir. Fakat ilerleyen yıllarda oluşan bu fazla yağış durumu için barajın durumu kontrol edilmelidir. Taşkın durumları denetlenmelidir. İleride görülmesi muhtemel olağanüstü nemli dönemler için risk analizleri yapılmalıdır.

-Çalışmada, bu bölge kuraklık açısından orta nemli-orta kurak olarak görülmüştür. Ancak, kuraklığa eğilimlidir denilebilir.

-Meteorolojik kuraklık, bazı zamanlarda hidrolojik kuraklığa neden olabilir. Çok kurak bir dönemde,baraja gelen debi azalır ve şehre sağlanan içme suyunda yetersizlikler oluşabilir.

Bu sonuçlar doğrultusunda, Bursa için kuraklığa karşı alınabilecek birkaç önlem söyleyebiliriz. Kuraklık önlem planı oluşturmak,su kaynaklarımızı bilinçli kullanmak bunlardan bazılarıdır. Genel olarak iklim değişikliğini önlemek adına da tedbirler alınabilir. Bu bağlamda, nehir havza yönetim planları hazırlamak, iklim değişikliğinin su kaynaklarına etkisi ile ilgili çalışmalar yapmak, Türkiye'nin “ortak ve farklılaştırılmış sorumluluklar” ilkesi çerçevesinde iklim değişikliğine neden olan sera gazı emisyonlarını düşürmeye çalışmak, bu amaçla fosil yakıt tüketimini azaltmak, enerji verimliliğini artırmak, ormanları korumak ve geliştirmek gerekmektedir. Kuraklık için yapılan çalışmalarda ekolojik kurallar çerçevesinde davranılmalı, doğaya ve ekosistemlere zarar veren büyük ölçekli girişimlerden uzak durulmalıdır. Akarsuları, gölleri ve sulak alanları koruyan, bozulan yerlerde ekosistemi restore eden, suyu tasarruflu ve gerektiği kadar kullanmayı sağlayacak sulama sistemleri kuran, su kullanımında önceliği tarımsal ve evsel kullanıma veren, suların sanayi ve atıklarla kirletilmesinin önüne geçen bir yaklaşım benimsenmelidir. 


\section{Kaynakça}

[1] https://www.mgm.gov.tr/veridegerlendirme/kuraklik-analizi.aspx?d=yontemsinif

[2] Kadığlu M., Türkiye'de İklim Değişikliği Risk Yönetimi, Türkiye’nin Birleşmiş Milletler İklim Değişikliği Çerçeve Sözleşmesi'ne İlişkin İkinci Ulusal Bildirimi Hazirlik Faaliyetlerinin Desteklenmesi Projesi, T.C. Çevre ve Şehircilik Bakanlığı, Birleşmiş Milletler Kalkınma Programı (UNDP), 2012

[3] Topçu E., Seçkin N., (2013), L-Momentler ve Standart Yağış İndeksi (SPİ) yardımıyla Seyhan Havzası kuraklık analizi, Ç.Ü Fen ve Mühendislik Bilimleri Dergisi, 29(1), 19-28.

[4] Gocic M., Trajkovic S., (2014), Spatiotemporal characteristics of drought in Serbia, Journal of Hydrology, 510, $110-123$.

[5] Zarch M.A.A., Sivakumar B., Sharma A., (2015), Droughts in a warming climate: A global assessment of Standardized precipitation index (SPI) and Reconnaissance drought index (RDI), Journal of Hydrology, 526, $183-$ 195.

[6] Guhathakurta P., Menon P., Inkane PM., Krishnan U., Sable S.T., (2017), Trends and variability of meteorological drought over the districts of India using standardized precipitation index, Journal of Earth System Science, 126:120.

[7] Labedzki L., (2017), Categorical Forecast of Precipitation Anomaly Using the Standardized Precipitation Index SPI, Water, 9(8), 1- 14.

[8] http://www.bursadakultur.org/bursanin_cografyasi2.htm

[9] https://www.buski.gov.tr/tr/icerik/doganci baraji 565

[10] McKee T.B., Doesken N.J., Kleist J., (1993), The relationship of drought frequency and duration to time steps, Preprints, 8th Conference on Applied Climatology, January 17-22 Anaheim, California, ss.179-184.

[11] Guttman N.B., (1998), Comparing the Palmer Drought Index and the Standardized Precipitation Index, Journal of American Water Resources Association, 34(1), 113-121.

[12] Guttman N.B., (1999), Accepting the Standardized Precipitation Index: A calculation algorithm, Journal of American Water Resources Association, 35(2), 311-322.

[13] Thom H.C.S., (1958), A note on the Gamma Distribution, Monthly Weather Review, 86(4), 117-122

[14] Mckee, T.B., Doesken, N.J., Kleist, J., 1995. Drought Monitoring with Multiple Time Scales. American Meteorological Society, Proceeding of The 9th Conference on Applied Climatology, January 15-20, pp.233-236, Boston.

[14] Özgürel, M., Pamuk, G., Topçuoğlu, K., 2003. Ege Bölgesi Koşullarında Farklı İki Kuraklık İndisinin Karşılaştırılması. Ege Üniv. Ziraat Fak. Derg. 40 (1): 95-102.

[15] http://www.p005.net/analiz/korelasyon-analizi 